\title{
Research on the Development Trend of English Teaching under the Background of Autonomy and Exploratory Learning
}

\author{
Tieyuan Wei \\ School Of Foreign Studies, Yulin Normal University, \\ Yulin,Guangxi, 537000 China
}

\begin{abstract}
In this paper, we conduct research on development trend of the English teaching under the background of autonomy and exploratory learning. With the advent of the era of knowledge economy, especially in the knowledge economy, on the basis of the information age, knowledge update speed greatly accelerated, if not keenly study effectively in the face of rapidly changing world, no individual or organization is likely to be the era of rapid development. Cultivate students' autonomous learning ability is supposed to be one of the most basic content of modern quality education. Under this basic background, we conduct research on the novel education pattern for English teaching with the proper combination of autonomy and exploratory learning. The empirical analysis illustrates effectiveness and feasibility of our methodology that will be meaningful.
\end{abstract}

Keywords- Development Trend, English Teaching, Autonomy, Exploratory Learning.

\section{Introduction}

Teaching English as a foreign language has a history of more than one hundred years. Long EFL are native speakers of English as a learning content, and as a measure of success and failure. However, under the general background of the globalization, expanding the scope of using English as objects of communication in English may be from British and the American countries, but more to do with the non-native English speakers to communicate the world at present the number of non-native speakers in English communication was far more than the number of native speakers.

English teaching in China has long been follows the EFL concept, basic is British English and basic American English as the evaluation standard of success for Chinese learners of the English, both the accuracy of the pronunciation, vocabulary, grammar, or pragmatic appropriateness, all want to close to the native language specification. According to the literature review, the state-of-the-art methods of the English course system could be summarized as follows. (1) General English courses, including the basic language skills and advanced language skills course two categories. The basic language skills course is for students to adapt to college English learning styles and learning strategies to transitional course, after the repair should reach the general requirements of the university English four levels. (2) ESP courses, including general academic English and professional English two categories of courses. The former mainly training interdisciplinary academic oral communication and the primary written communication skills, namely English for academic exchanges, content is to develop how to listen to lectures, taking notes, to participate in the academic discussions, to conduct academic presentations, write literature review and essay need language skills, etc. The latter is based on certain professions demand for English teaching, the content of courses such as business English, engineering English. (3) General English courses are divided into the humanistic literacy class English courses for English course and international communication two categories, to continue to improve the students' language application ability, to cultivate cross-cultural communication skills, so that students in a familiar with the western culture at 
the same time has the ability to spread the Chinese civilization [1-3].

In the wave of change to adapt to the era in the development of science and education innovation, the ideas of the inquiry-based learning have received national education attaches great importance to the science. People realize that today's education is not only in the past and the spread of knowledge accumulation, must keep pace with the times again at the same time, considering the requirement of the social development in the future. Implementation of basic inquiry-based learning, which requires teachers to create a democratic, harmonious, freedom, equality of teaching environment, teachers and students interact, maximize students' learning initiative, provide free learning space for students to let each student's study enthusiasm while the creative is improved, and play. Within this scope, we could summarize the corresponding features as the follows. (1) Practicalness. Inquiry-based learning is the main body of students practice activity as the main line of the learning process. (2) Cooperative. The Inquiry-based learning is the cooperation and exchange of the learning process the classroom teachers and students to discuss and solve the problem of the questions existing in the experimental process. Students in the process of basic communication study, fully express their opinion, the present study achievement and feel the joy of success. (3) Procedural. Inquiry is the objective of science learning, and the scientific way of learning. Experience is given priority to with inquiry learning activities is an important way for general students to learn science.

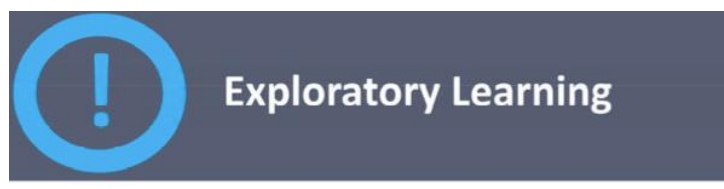

- You are given a goal

- You aren't told how to reach it.

- You can fail (and be told that you failed)

- You can succeed.

- Delight comes when you figure it out on your own.

Scarv part: You have to believe the user is smart

Figure 1. The Principles of the Exploratory Learning

In this paper, we conduct research on development trend of English teaching under the background of autonomy and exploratory learning which will be discussed in detail in the later sections.

\section{Our Proposed Methodology}

The Principles of the Exploratory Learning. Inquiry-based learning is that the students under the guidance of teachers, the independent active learning process. Students take the initiative to choose and determine the project, and in the process of the exploring, the initiative to acquire knowledge and apply knowledge to solve the problem of learning activities. Teacher's task is to arouse the enthusiasm of students, prompted to acquire knowledge, develop their own ability, do you found the problem, ask questions, analyze and solve problems, but also for the students' study to explore the situation and to establish inquiry atmosphere, promote exploration development to grasp the explore in depth [4-5].

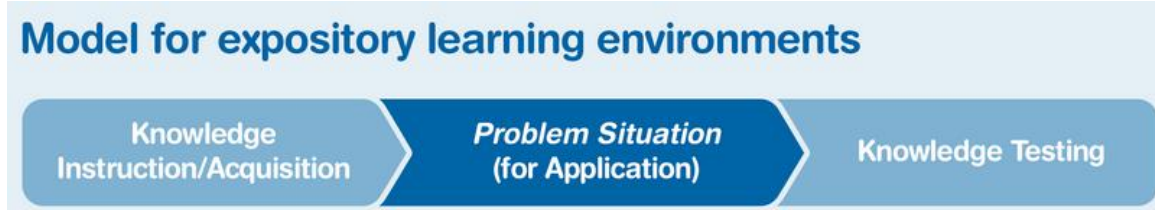

Figure 2. The General Steps of the Exploratory Learning 
Inquiry-based learning advocated "knowledge" on the problem, in reality, in certain situations, lets the student experience in exploration, discovery, and solve the problem in the process of the learning methods, and foster the desire of lifelong learning. Inquiry-based learning instructional design should consider not only the teaching goal, but also consider creating situation is one of the most important content in the teaching design, and create the suitable situation, induce the curiosity of the students, encouraging students to bold attempt to enrich the students' imagination and to cultivate the students' personality. The content of the inquiry learning is not specific knowledge system, but based on the students' interests and talents, can study a problem and also can study the issue of the interdisciplinary comprehensive, wide range of topics.

This is the comprehensive inquiry learning as research learning in terms of the types of activities and also has greater openness can according to the study by the students to determine the content and form, method can also be free to choose and this is the openness of the research-based study. As an optimized teaching situation is full of emotion and reason of motivate students take the initiative to participate in the fundamental guarantee of learning, it can stimulate students' learning interest and the desire to explore, promote the understanding and mastering of knowledge and methods, we can also make it in the process of knowledge acquisition to improve thinking and cognitive ability, more can make students experience the aesthetic feeling in the harmonious two-way communication between the teachers and students and cultivate the character.

The Principles of Autonomous Learning. Autonomous learning has been an important problem of the concern of pedagogy and psychology. Researchers in the field of the education, to cultivate students' autonomous learning ability as an important education goal, the paper mainly discusses the effective teaching methods to promote students' autonomous learning. In the field of psychology, the researchers focused on the various factors influencing the students' autonomous learning, as well as the inherent psychological mechanism of the occurrence and development of independent learning. It can play a role of different levels of autonomous learning center provide different levels of guidance to promote the development of students' autonomous learning ability. Its role can be summarized as follows. (1) Classroom teaching and simulation language is the bridge to the real world, namely the learners learn the target language in class, and use the target language in the center of the autonomous learning. (2) Consciousness cultivation, namely the outstanding self-learning management, such as the goal setting, and process monitoring, so as to cultivate and improve the learners' awareness of the learning process. (3) Individual differences to tolerate property, that is, different learning style, level and the learners can learn the purpose of the pursuit of their goals and satisfy their own interest.

The concept of autonomous learning in the field of language is put forward and the development is the embodiment of the students as the center of language teaching thought and continues. It conforms to the foreign language teaching research object from the object gradually transition to a main body of this trend. In foreign language teaching to develop students' autonomous learning, its rationality and necessity can get proof from many aspects that about the development of autonomous learning in the field of foreign language teaching and learning, the largest number of discussion, the definition of the autonomous learning, in a nutshell, autonomous learning generally refers to learners consciously only determine learning objectives, select learning methods, monitoring learning process with evaluation process of learning results. Obviously, the autonomous learning center requires learners to take more responsibility than class that also puts forward new requirements for 
the use of learning strategies. Through understanding the students' learning strategy use, we can be targeted on the basis of strategy training, help students to raise awareness of strategy use and avoid using improper strategy, develop independent learning center in the independent learning effectiveness, so as to cultivate the students' autonomous learning ability. In the figure 3, we show the mentioned concepts [6].

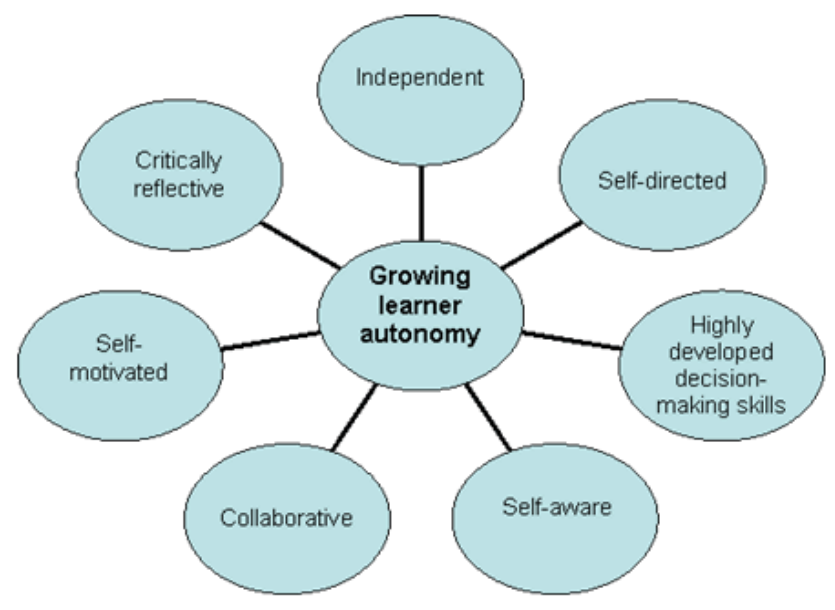

Figure 3. The Architecture of the Autonomy Learning Methodology

The University Teaching. In modern college teaching, imparting knowledge is the important, but more important is to cultivate the correct method of study and strong self-learning ability, cultivate students' scientific spirit and a sound personality. In current university, training mode and teaching process, both theoretical teaching and practical teaching, are not really reflected this spirit. Therefore, a thorough reform of the traditional education mode, truly quality education can be integrated with the university teaching process is the key to promote the reform of college teaching. In this sense, quality education is not knowledge primarily education outside the added new content, but in the knowledge of education itself that is fundamentally reform the existing teaching contents, teaching methods, as teaching management mode, professional settings, system settings, etc. In general, quality education will inevitably lead to the profound changes of the concept of quality of education.

We will deepen the reform of the teaching content and form to the student as the main body of the autonomous learning mechanism. But some of the common basis should be allowed to teachers on the teaching content of the personalized, allowing the diversification of teaching material and encourage teachers to explore various beneficial to inspire and mobilize students' learning enthusiasm is helpful to inspire the learning innovation of the teaching methods from the system to strengthen the students' autonomous learning links such as practice and experiment design.

The Further Development of the English Teaching. A high level of construction of teaching material is an important basic work of college English teaching reform. Of college English teaching in the new period puts forward higher requirements on the teaching material construction, therefore, the author first to combing the current situation of the college English textbooks, and combined with the main demand of the college English teaching in the new period, analyses the development trend of the college English teaching material construction, provides some references for the reform of the college English textbooks. Institutions of higher learning of college English 
course system construction goal should be: with professional teaching as the center, with professional ability and the language level of organic integration, for the purpose of training to adapt to international competition, to be able to use the foreign language talents engaged in professional work. However, in the concrete implementation process should take into account various levels of colleges and universities training goal difference, students' actual language level, the teachers troop construction, etc.

In the process of building curriculum system should also note: according to the characteristics and requirements of the different professional, in the course system large system under the condition of a certain total teaching hours, to the reasonable distribution of different types of subsystem, to correctly understand the degree of the different modules, curriculum design, reasonable distribution of class. According to the different situation of each school, college, and make corresponding adjustment on three modules, flexible arrangements, in a word, the college English subsequent courses has become an indispensable part of college English course system and the construction of such a special and complex system, need to have a clear mind and talents training target to guide, combinative oneself is actual exploration also need to colleges and universities [7-8].

To develop educatees creativity for the purpose, in order to cultivate creative talent as the goal of education thought, education idea, the basic principle of education, education method, education of comprehensive education system is created, although it is not an independent education level or type of education, it can be combined with the existing various kinds of education, to infiltrate the school education, family education and social education of all levels, all areas. In school education, creation education is to cultivate people's creativity of purposeful, planned and organized activities. Its object is the student practice as student's body and mind constitute important elements of creation education and teaches students how to explore and study objective facts to gain new knowledge is the concrete embodiment of creation education in various disciplines teaching.

\section{Conclusion}

In this paper, we conduct research on development trend of English teaching under the background of autonomy and exploratory learning. With the development of knowledge economy and science and the technology, society of personal knowledge updating and knowledge level of demand is higher and higher, a person just by what they have learned in school knowledge is not enough, everyone must hold lifelong self-directed learning, visible autonomous learning has become a contemporary college student for a way of learning. To some extent, this will affect and restrict the students' autonomous learning. Therefore, it is necessary to carry out the influence factors of college students' autonomous learning quantity and qualitative research, to facilitate better guides the work of education, and enrich and develop education theory. In the future, for further development and analysis of the better mode of English teaching, we will combine more state-of-the-art reviews and references for modification.

\section{References}

[1] Appleman, Deborah. Critical encounters in secondary English: Teaching literacy theory to adolescents. Teachers College Press, 2014.

[2] Lammers, Jayne C., Jen Scott Curwood, and Alecia Marie Magnifico. "Toward an affinity space methodology: Considerations for literacy research." English Teaching 11.2 (2012): 44.

[3] Hawkins, Samantha J. "Guilt, missed opportunities and false role models: A look 
at perceptions and use of the first language in English teaching in Japan." JALT Journal 37.1 (2015): 29-42.

[4] Sun, Dongyun. "From communicative competence to interactional competence: A New Outlook to the Teaching of Spoken English." Journal of Language Teaching and Research 5.5 (2014): 1062-1070.

[5] Mantei, Jessica, and Lisa Kervin. "Interpreting the images in a picture book: Students make connections to themselves, their lives and experiences." English Teaching 13.2 (2014): 76.
[6] Moss, Gemma. "Literacy policy and English/literacy practice: Researching the interaction between different knowledge fields." English Teaching 11.1 (2012): 104.

[7] Chen, L. I. "Implication of Relevance Theory on College English Reading Teaching Mode [J]." Journal of Chengde Petroleum College 1 (2012): 021.

[8] Knapp, Karlfried. "English as an international lingua franca and the teaching of intercultural communication." Journal of English as a Lingua Franca 4.1 (2015): 173 